\title{
Are myofibroblasts activated in idiopathic carpal tunnel syndrome? An immunohistochemical study
}

\author{
İdiopatik karpal tünel sendromunda miyofibroblastlar aktifleşir mi? İmmünohistokimyasal bir çalışma
}

\author{
Murat Yeşil, MD., A. Kadir Bacakoğlu, MD., Mehmet Doğan, MD.
}

Department of Orthopedics and Traumatology, Medical Faculty of Dokuz Eylül University, İzmir, Turkey

\begin{abstract}
Objectives: This study aims to investigate whether myofibroblasts participate in the fibrotic process of idiopathic carpal tunnel syndrome (CTS).

Patients and methods: Forty patients (12 males, 28 females; median age $50.85 \pm 11.2$ years; range 30 to 71 years) who were operated in our clinic between March 2010 and August 2010 were included in the study. Twenty-five idiopathic CTS patients were assigned to the study group, and 15 trauma patients were assigned to the control group. Samples were taken from both transverse carpal ligament and subsynovial connective tissue (SSCT) of participants and they were analyzed by immunohistochemical method. Four immunohistochemical markers were used to analyze myofibroblast existence and vascular wall thickness (alpha smooth muscle actin [ $\alpha$-SMA]), collagen type IV antibodies, and T (CD3) and B (CD20) lymphocytes.
\end{abstract}

Results: The existence of myofibroblasts ( $\alpha$-SMA) in SSCT of patients who were in early phase of idiopathic CTS was shown through the positive reaction of their antibodies with fibroblasts. A significantly increased reaction of $\alpha$-SMA and collagen antibodies in vascular structure of SSCT demonstrated increased vascular wall thickness and vascularity in the study group $(\mathrm{p}<0.01)$. No significant difference was detected between the two groups in terms of $\mathrm{T}$ and B lymphocyte antibody reaction (inflammation).

Conclusion: The findings of this study indicate a potential for myofibroblasts to be activated during the early phase of the disease and contribute to the onset of disease. Further studies with larger sample sizes would be of great assistance in determining the role of myofibroblasts in idiopathic CTS.

Keywords: Carpal; fibrosis; idiopathic; myofibroblast; syndrome.

Carpal tunnel syndrome (CTS) is the most common compression neuropathy worldwide. ${ }^{[1]}$ It has been previously suggested that a discordance between tissue volume and the size of the tunnel might cause
Amaç: $\mathrm{Bu}$ çalışmada miyofibroblastların idiopatik karpal tünel sendromundaki (KTS) fibrotik süreçte rol oynayıp oynamadığ 1 araştırıldı.

Hastalar ve yöntemler: Mart 2010-Ağustos 2010 tarihleri arasında kliniğimizde ameliyat edilen 40 hasta (12

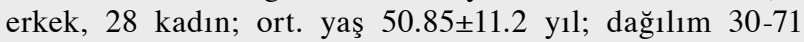
yıl) çalışmaya alındı. Yirmi beş idiopatik KTS hastası çalışma grubuna, 15 travma hastası kontrol grubuna dahil edildi. Katılımcıların hem transvers karpal ligaman hem de subsinovyal bağ dokusundan (SSBD) örnekler alındı ve bunlar immünohistokimyasal yöntem ile analiz edildi. Miyofibroblast varlığını ve damar duvar kalınlığını (alfa düz kas aktin [ $\alpha$-DKA]), kollajen tip IV antikorları, $\mathrm{T}$ (CD3) ve $\mathrm{B}$ (CD20) lenfositleri incelemek için dört immünohistokimyasal işaretleyici kullanıldı.

Bulgular: İdiopatik KTS'nin erken aşamasında olan hastaların SSBD'sinde miyofibroblast varlığı $(\alpha$-DKA) antikorlarının fibroblastlar ile pozitif reaksiyonu yoluyla gösterildi. Subsinovyal bağ dokusunun vasküler yapısında $\alpha$-DKA ve kollajen antikor reaksiyonunun anlamlı şekilde artmış olması, çalışma grubunda damar duvar kalınlığı ve vaskülaritenin artmış olduğunu gösterdi $(\mathrm{p}<0.01)$. İki grup arasında $\mathrm{T}$ ve $\mathrm{B}$ lenfosit antikor reaksiyonu açısından anlamlı fark saptanmadı (inflamasyon).

Sonuç: Bu çalışmanın bulguları, miyofibroblastların hastalığın erken döneminde aktifleşip hastalığın başlangıcına katkı yapma olasılıkları olduğuna işaret etmektedir. İleride yapılacak daha büyük örneklem sayılı çalışmalar miyofibroblastların idiopatik KTS'deki rolünün anlaşılmasına büyük katkı sağlayacaktır.

Anahtar sözcükler: Karpal; fibrozis; idiopatik; miyofibroblast; sendrom.

this disease. ${ }^{[2]}$ Previous studies have demonstrated neither morphometric nor biomechanical differences between transverse carpal ligaments in idiopathic CTS. ${ }^{[3]}$

- Received: May 22, 2014 Accepted: October 02, 2014

- Correspondence: Murat Yeşil, M.D. Afyon Kocatepe Üniversitesi Tıp Fakültesi Ortopedi ve Travmatoloji Anabilim Dalı, 03103 Afyonkarahisar, Turkey. Tel: +90 272 - 4440304 Fax: +90 272 - 2463322 e-mail: drmurat17@hotmail.com 
Fibrosis, the most common histological finding in idiopathic carpal tunnel syndrome, is observed in subsynovial connective tissue of carpal tunnel (SSCT) which is a meshwork of areolar connective tissue and a vascular network. ${ }^{[4,5]}$ Some authors, we currently agree, advocate that subsynovial connective tissue is exposed continuously to shearing stress, and thus responds with a wound healing reaction which gradually increases fibrosis. ${ }^{[6]}$ This phenomenon results in a vicious cycle of increased shearing force throughout SSCT because fibrosis increases both the stiffness of the tissue and shearing modulus that inevitably result in shearing force to be much more effective. ${ }^{[7,8]}$

Fibroblasts are effective mechano-responsive cells. ${ }^{[9]}$ It is shown that fibroblasts respond to tension, compression and shearing forces with expression of different genes, and they can even change their phenotype to more fibrotic cells such as myofibroblasts. ${ }^{[10,11]}$

Myofibroblast, transitioned from a fibroblast, is a connective tissue cell which has both fibroblast and muscle cell characteristics. Myofibroblasts contract extracellular matrix and synthesize collagen as well. Alpha smooth muscle actin ( $\alpha$-SMA) is the most reliable marker for myofibroblasts. ${ }^{[1]}$ Transforming growth factor beta (TGF- $\beta 1$ ) has an important role for myofibroblastic transformation of fibroblasts and it shows its intracellular effects via some intracellular effector molecules named as Smad proteins. ${ }^{[12]}$ In this context; blockage of TGF- $\beta /$ Smad protein cascade have created new treatment strategies for fibrotic diseases. ${ }^{[13]}$

We hypothesize that some of the fibroblast population change their phenotype to myofibroblasts, and by then this transformation triggers the fibrotic process which leads to an abnormal increment of tissue volume resulting in compression of median nerve within carpal tunnel. A comprehensive review of literature demonstrated that there are only few studies about myofibroblast activation in idiopathic CTS. ${ }^{[14]}$

Unveiling both the role and presence of myofibroblasts in idiopathic CTS is significantly relevant for clinical practice because there are new strategies that block fibroblast/myofibroblast transformation cascade at different levels and it may be possible to utilize these strategies also for CTS. ${ }^{[13,15]}$ In this study, we aimed to investigate whether myofibroblasts participate in the fibrotic process of idiopathic CTS.

\section{PATIENTS AND METHODS}

The study was designed as a case-control prospective study and conducted between March-August 2010. We got approval from the ethics committee of Dokuz Eylül University (No: 2010/01-04) before commencing the study. Our study included 40 patients (12 males, 28 females; median age $50.85 \pm 11.2$ years; range 30 to 71 years) who underwent surgery in Orthopaedics and Traumatology Department of Dokuz Eylül University. All participants signed an informed consent form before participation. Patients who underwent procedure for idiopathic CTS were included in study group while those who had surgery for flexor tendon injury or distal radius fracture (volar plate) were assigned to control group. The study group consisted of 25 patients (mean age 54.88 \pm 9.37 ) and control group was comprised of 15 patients (mean age $44.13 \pm 11.16$ ) (Table I, II).

As no exact criteria for CTS diagnosis have been defined up to date, diagnosis was based on a combination of symptoms and nerve conduction studies. Exclusion criteria were pathologies that cause secondary CTS (diabetes mellitus, autoimmune disorders, thyroid disorders, pregnancy, renal failure

TABLE I

Demographic data

\begin{tabular}{|c|c|c|c|c|c|c|}
\hline \multirow[t]{2}{*}{ Procedure } & \multicolumn{2}{|c|}{${ }^{*}$ Control group $(n=15)$} & \multicolumn{2}{|c|}{ Study group $(\mathrm{n}=25)$} & \multicolumn{2}{|c|}{ Total $p^{*}$} \\
\hline & $\mathrm{n}$ & $\%$ & $\mathrm{n}$ & $\%$ & $\mathrm{n}$ & $\%$ \\
\hline Surgery for CTS & 0 & 0 & 25 & 100 & 25 & 62.5 \\
\hline Surgery for distal radius fracture & $12^{* *}$ & 80.0 & 0 & 0 & 12 & 30.0 \\
\hline Surgery for flexor tendon injury & 3 & 20.0 & 0 & 0 & 3 & 7.5 \\
\hline \multicolumn{7}{|l|}{ Symptom duration } \\
\hline $0-12$ months & & & 10 & 40 & & \\
\hline$>12$ months & & & 15 & 60 & & \\
\hline
\end{tabular}


TABLE II

Age distribution

\begin{tabular}{|c|c|c|c|c|c|c|c|c|c|c|}
\hline & \multicolumn{3}{|c|}{ Control group } & \multicolumn{3}{|c|}{ Study group } & \multicolumn{3}{|c|}{ Total } & \multirow[b]{2}{*}{$p$} \\
\hline & $\mathrm{n}$ & $\%$ & Mean $\pm S D$ & $\mathrm{n}$ & $\%$ & Mean $\pm S D$ & $\mathrm{n}$ & $\%$ & Mean $\pm S D$ & \\
\hline Age & & & $44.13 \pm 11.2$ & & & $54.88 \pm 9.4$ & & & $50.85 \pm 11.2$ & 0.002 \\
\hline \multicolumn{11}{|l|}{ Gender } \\
\hline Female & 5 & 33.3 & & 23 & 92 & & 28 & 70 & & \multirow{2}{*}{0.001} \\
\hline Male & 10 & 66.7 & & 2 & 8 & & 12 & 30 & & \\
\hline
\end{tabular}

TABLE III

Types of injuries and time of surgery in control group

\begin{tabular}{|c|c|c|c|c|}
\hline \multirow[b]{2}{*}{ Control group } & \multicolumn{4}{|c|}{ Time of surgery } \\
\hline & 1-2 weeks after injury & 2-4 weeks after injury & $>1$ month after injury & Total number \\
\hline Distal radius fracture ${ }^{\star}$ & $10^{*}$ & 2 & - & 12 \\
\hline Zone IV flexor tendon injury & 3 & - & - & 3 \\
\hline
\end{tabular}

* One patient was excluded as he was diagnosed with rheumatoid arthritis.

and history of dialysis, acromegaly, space-occupying lesions in carpal tunnel, rheumatoid arthritis, gout disease, amyloidosis), flexor tendinitis , morbid obesity, body mass index higher than 40 , traumatic injury in the same extremity (for study group) and peripheral nerve disease. Also anteroposterior and lateral wrist radiographs were taken to exclude bony lesions that limit tunnel space and might result in CTS. Fifteen patients were excluded before participation as they had one or more of these criteria, and one patient was excluded from control group since he was diagnosed with rheumatoid arthritis.

Twenty-five patients in the study group were assigned into two groups according to their symptom duration (Table I, II).

Control group was comprised of 15 patients. We chose zone IV flexor tendon injuries and distal

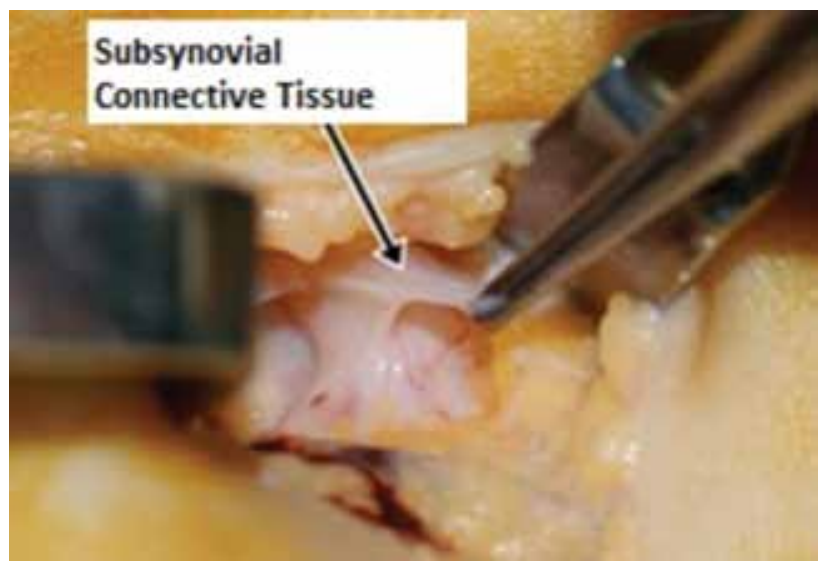

Figure 1. Subsynovial connective tissue. radius fractures necessitating surgical intervention with volar approach, and carpal tunnel release was already a part of these procedures in the control group. Therefore, no additional dissection or incision was made as part of our recent study (Table III).

\section{Sample harvesting}

Samples with a volume of $20-50 \mathrm{~mm}^{3}$ were harvested from both subsynovial connective tissue (SSCT) (Figure 1) and transverse carpal ligament (Figure 2) for histopathological evaluation. For standardization; SSCT samples were taken around flexor digitorum superficialis tendon of middle finger, closest and superficial tendon just lying along ulnar side of median nerve without any lumbrical muscle or tendon insertion, the same localization as previous studies have mentioned. ${ }^{[16]}$

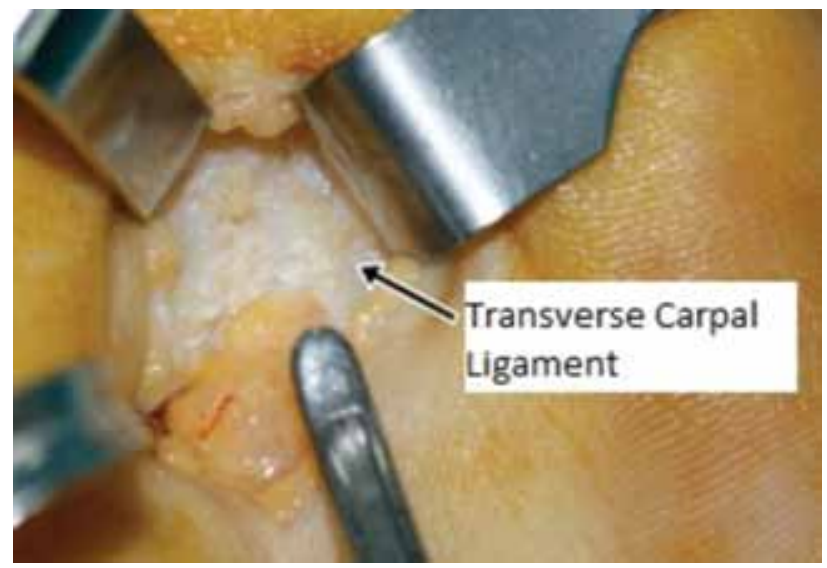

Figure 2. Transverse carpal ligament. 

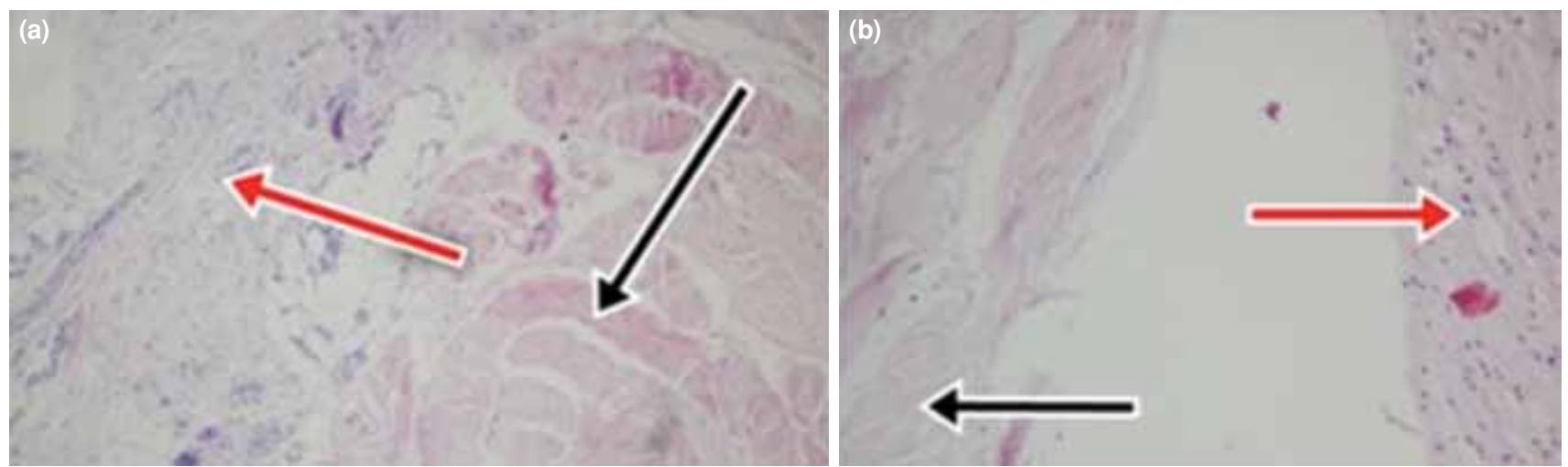

Figure 3. (a) Transverse carpal ligament (dark arrow) and subsynovial connective tissue (red arrow) sample from study group (b) Transverse carpal ligament (dark arrow) and subsynovial connective tissue sample (red arrow) from control group (no pathological changes except for edema (H-E x 60).

\section{Histopathological evaluation}

Histopathological evaluation was carried out by a pathologist and an orthopaedic surgeon as doubleblinded by semi quantitative method. Fibrosis, inflammation and collagen type IV reaction were classified as $(+)$ mild, $(++)$ moderate and $(+++)$ severe.

We investigated histopathological findings such as stage of fibrosis, vascular proliferation, vascular wall thickness, presence of chronic inflammation (CD3 and CD20 stain), myofibroblast existence and type IV collagen presence. Fibrosis was investigated with Hematoxylin and eosin stain (H-E stain) and myofibroblast existence, vascular proliferation and vascular wall thickness were investigated by $\alpha$-SMA stain on both transverse carpal ligament and SSCT tissue samples. We evaluated chronic inflammation with CD3, CD20 stains and collagen type IV existence with specific immunohistochemical stains. One of the samples from control group was excluded as it had histopathological findings of rheumatoid arthritis.

\section{Statistical analysis}

Number Cruncher Statistical System 2007\&PASS (Power Analysis and Sample Size) 2008 Statistical Software (Utah, USA) program was used for statistical analyses. Descriptive and quantitative data were analyzed with Kruskal Wallis test for comparison of parameters with abnormal distribution. MannWhitney U test was applied for comparison of control and study groups and for determination of the group that caused the significant difference. Qualitative data were analyzed with chi-square test and Fisher's Exact chi-square test, and $p$ values of $<0.05$ were considered significant.

\section{RESULTS}

There was a significant difference $(\mathrm{p}<0.01)$ in terms of age and gender distribution between two groups. Study group was significantly older and consisted of more females than control group $(\mathrm{p}<0.01)$ (Table I, II).

\section{Transverse carpal ligament}

We found no significant difference between transverse carpal ligament samples. Edema was a common finding in all samples but there was no sign of fibrosis, inflammation, vascular proliferation, increment of vascular wall thickness and myofibroblast existence in transverse carpal ligament (Figure 3).

\section{Subsynovial connective tissue (SSCT)}

As shown in Table III, edema was a common finding in both study and control groups and fibrosis was significantly more common in SSCT of study group (Figure 4).

Study group had significantly increased fibrosis ( $>0.05)$ (Table IV) (Figure 4). Also, study group had significantly increased vascular wall thickness in SSCT ( $<<0.01)$. Forty-eight percent of study group had increased vascular wall thickness in SSCT whereas $7.1 \%$ of control group had the same finding (Figure 5) (Table IV).

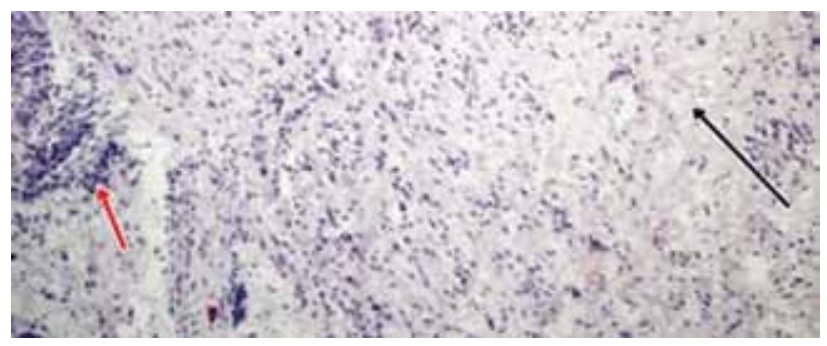

Figure 4. Fibrosis. Increased cellularity of fibroblasts (red arrow) and irregular collagen fibers (dark arrow) (H-E x 100). 
TABLE IV

Histopathological findings in subsynovial connective tissue of carpal tunnel

\begin{tabular}{|c|c|c|c|c|c|c|c|}
\hline & \multicolumn{2}{|c|}{ Control group $(n=14)$} & \multicolumn{2}{|c|}{ Study group $(n=25)$} & \multicolumn{2}{|c|}{ Total } & \multirow[b]{2}{*}{$p$} \\
\hline & $\mathrm{n}$ & $\%$ & $\mathrm{n}$ & $\%$ & $\mathrm{n}$ & $\%$ & \\
\hline \multicolumn{8}{|l|}{ Edema } \\
\hline$(+)$ & 14 & 100 & 25 & 100 & 39 & 100 & - \\
\hline \multicolumn{8}{|l|}{ Fibrosis } \\
\hline$(-)$ & 12 & 85.7 & 8 & 32 & 20 & 51.3 & \multirow{3}{*}{$0.004^{*}$} \\
\hline Mild & 2 & 14.3 & 10 & 40 & 12 & 30.8 & \\
\hline Moderate & 0 & 0 & 7 & 28 & 7 & 17.9 & \\
\hline \multicolumn{8}{|l|}{ Inflammation } \\
\hline$(-)$ & 13 & 92.9 & 21 & 84.0 & 34 & 87.2 & \multirow{2}{*}{$\ddagger 0.636$} \\
\hline Mild & 1 & 7.1 & 4 & 16.0 & 5 & 12.8 & \\
\hline \multicolumn{8}{|c|}{ Vascular proliferation } \\
\hline$(+)$ & 3 & 21.4 & 7 & 28.0 & 10 & 25.6 & \multirow{2}{*}{0.652} \\
\hline$(-)$ & 11 & 78.6 & 18 & 72 & 29 & 74.4 & \\
\hline \multicolumn{8}{|c|}{$\begin{array}{l}\text { Increment of vascular } \\
\text { wall thickness }\end{array}$} \\
\hline$(+)$ & 1 & 7.1 & 12 & 48.0 & 13 & 33.3 & \multirow{2}{*}{$0.009^{*}$} \\
\hline$(-)$ & 13 & 92.9 & 13 & 52.0 & 26 & 66.7 & \\
\hline \multicolumn{8}{|l|}{ Myofibroblast } \\
\hline$(+)$ & 0 & 0 & 3 & 12.0 & 3 & 7.7 & \multirow{2}{*}{$\ddagger 0.540$} \\
\hline$(-)$ & 14 & 100 & 22 & 88.0 & 36 & 92.3 & \\
\hline \multicolumn{8}{|l|}{ CD 20} \\
\hline$(+)$ & 2 & 14.3 & 0 & 0 & 2 & 5.1 & \multirow{2}{*}{$\ddagger 0.123$} \\
\hline$(-)$ & 12 & 85.7 & 25 & 100 & 37 & 94.9 & \\
\hline
\end{tabular}

We were able to observe myofibroblast presence in SSCT of three samples from study group, and these samples belonged to patients who had symptom duration earlier than 12 months (Table V, Figure 6). There was a significant relation involving myofibroblast existence and symptom duration $(\mathrm{p}<0.01)$. Collagen type IV reaction was observed in vascular structure of SSCT. Study group had significantly higher reaction rate for collagen type IV in SSCT $(\mathrm{p}<0.05)$ (Table VI, Figure 7).
There was no significant difference in terms of chronic inflammation and vascular proliferation between SSCT of control and study groups ( $>0.05)$. (Figure 8, Table VI).

\section{DISCUSSION}

Carpal tunnel syndrome is the most common compression neuropathy, and it is characterized by a discordance between tissue volume and the size of the tunnel..$^{[1,2]}$ Fibrosis of SSCT is a common
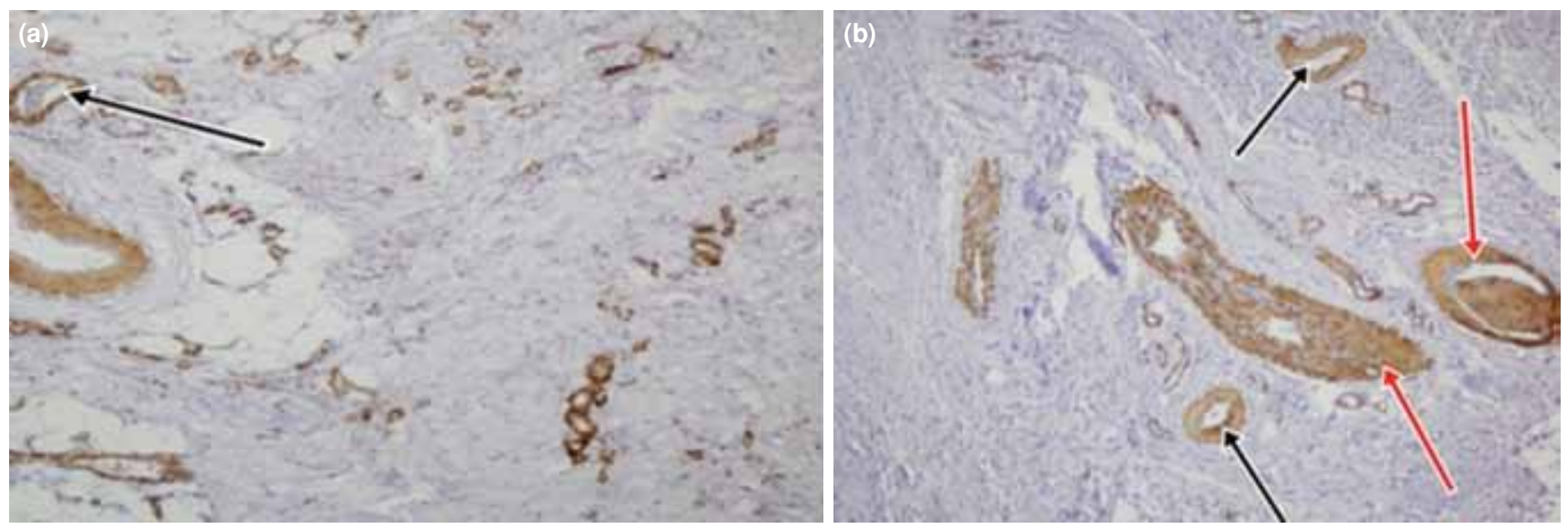

Figure 5. Vascular wall thickness: Alpha smooth muscle actin reacts with vascular smooth muscle (a) Normal vascular thickness (dark arrow) (b) Increased vascular thickness (dark arrow), narrowing of vascular gap (red arrow), (Anti-human smooth muscle actin $\mathrm{x}$ 100). 
TABLE V

Correlation between symptom duration and myofibroblast existence in study group

\begin{tabular}{|c|c|c|c|c|c|}
\hline & \multicolumn{4}{|c|}{ Myofibroblast } & \multirow[b]{3}{*}{$p$} \\
\hline & \multirow{2}{*}{$\frac{(+)}{n}$} & \multirow{2}{*}{$\frac{(-)}{\mathrm{n}}$} & \multicolumn{2}{|c|}{ Total } & \\
\hline & & & $\mathrm{n}$ & $\%$ & \\
\hline \multicolumn{6}{|c|}{ Symptom duration } \\
\hline $0-12$ months & 3 & 7 & 10 & 40 & $0.005^{\star}$ \\
\hline$>12$ months & 0 & 15 & 15 & 60 & \\
\hline
\end{tabular}

Chi square test; * $p<0.05$

histopathological finding in idiopathic CTS. ${ }^{[4,5]}$ Although some research has been carried out on increased fibrosis of SSCT in idiopathic CTS, the exact mechanism which induce or facilitate fibrosis has not been established yet. The major objective of this study was to identify myofibroblasts, a population of cells that primarily induce fibrosis, in SSCT. Thus, this study provides an opportunity to advance our knowledge of myofibroblast activation in idiopathic CTS, and this finding might have important implications for utilizing antifibrotic treatment strategies for the disease. ${ }^{[13,15]}$

Consistent with previous literature, our results did not suggest any evidence regarding fibrosis, vascular proliferation or increased vascular wall thickness in transverse carpal ligament samples. ${ }^{[3]}$ Except edema, our results for this tissue seemed even physiologic.

Inflammation showed no significant difference between SSCT samples of two groups. We revealed that $\mathrm{T}$ lymphocytes were more frequent than $\mathrm{B}$ lymphocytes. However, our results were not adequate to link CTS with any inflammatory process. So, we agree with previous studies that report "a noninflammatory fibrosis" in SSCT. ${ }^{[4]}$

Previous studies have reported that repetitive injury and mechanical stress on SSCT result in chronic wound healing reaction and fibrosis. ${ }^{[6]}$ Electron

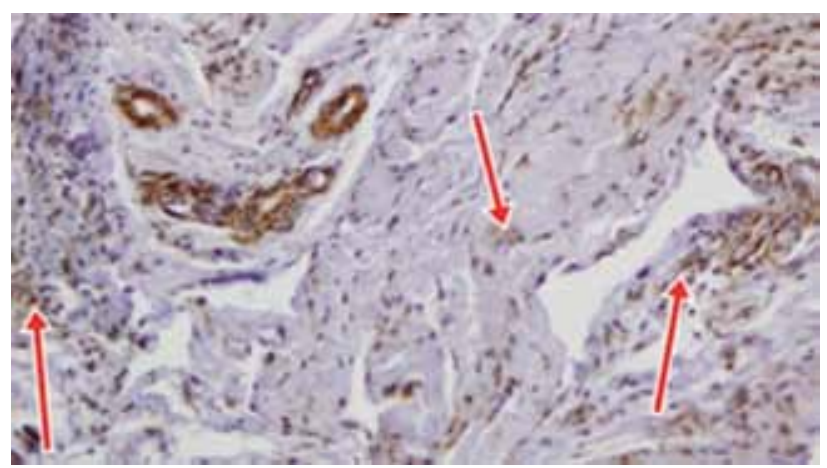

Figure 6. Myofibroblasts: Fibroblasts reacting (+) with alpha smooth muscle actin (arrows), (Anti-human smooth muscle actin $x$ 100).

microscope studies about SSCT report that changes in collagenous structure are mostly observed near tendons that are exposed to shearing stress. ${ }^{[17]}$ Then, fibrosis induces excessive collagen and extracellular matrix protein synthesis that cause reduction of volume and ensuing compression of median nerve. Consistent with previous literature, our results also suggest a significantly increased fibrosis of SSCT in study group.

There was no difference in vascular proliferation; however, vascular wall thickness was significantly increased in the study group. This can be attributed to low elastin level which is caused by either ischemia or fibrosis. In ischemia, tropoelastin gene expression is reduced and the balance between elastin and collagen is altered by collagen dominancy. ${ }^{[18]}$

To the best of our knowledge, no previous study has investigated collagen type IV in SSCT. It is typically located in basal lamina of vascular structure. We identified collagen type IV in vascular structure of SSCT, and it was significantly increased in study group. This evidence also suggests increased vascular proliferation and fibrosis in SSCT.

It is a matter of debate whether a wound healing process or fibroblastic activation triggers the process

TABLE VI

Collagen type IV antibody reaction according to groups

\begin{tabular}{|c|c|c|c|c|c|c|c|}
\hline \multirow[t]{2}{*}{ Collagen type IV } & \multicolumn{2}{|c|}{ Control group $(n=14)$} & \multicolumn{2}{|c|}{ Study group $(n=25)$} & \multicolumn{2}{|c|}{ Total } & \multirow[b]{2}{*}{$p$} \\
\hline & $\mathrm{n}$ & $(\%)$ & $\mathrm{n}$ & (\%) & $\mathrm{n}$ & $(\%)$ & \\
\hline Negative reaction & 2 & 14.3 & 9 & 36 & 11 & 28.2 & \\
\hline Mild reaction & 4 & 28.6 & 0 & 0 & 4 & 10.3 & $0.013^{*}$ \\
\hline Moderate reaction & 8 & 57.1 & 16 & 64.0 & 24 & 61.5 & \\
\hline Severe reaction & - & - & - & - & - & - & \\
\hline
\end{tabular}




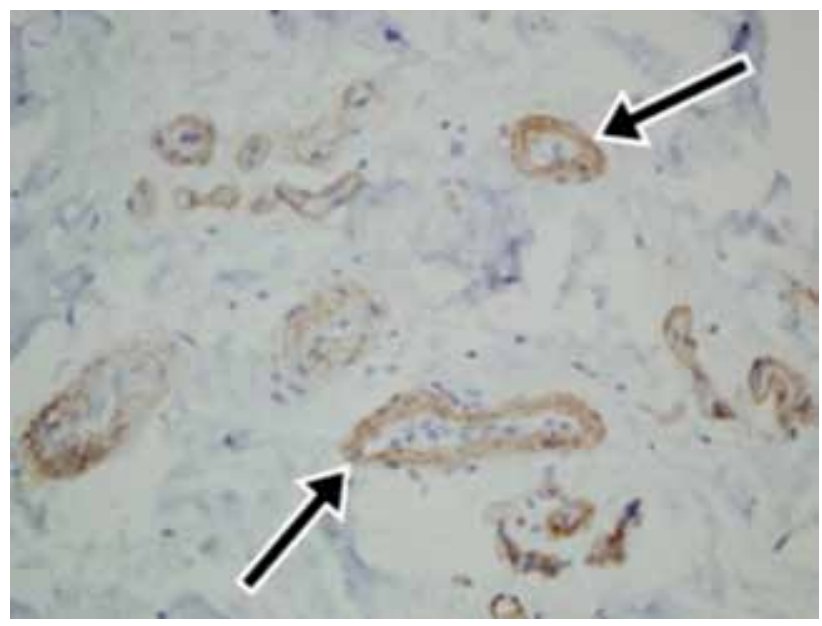

Figure 7. Collagen type IV in subsynovial connective tissue: basal lamina of vascular structure showed (+) reaction (arrows), (Anti-collagen type IV x100).

leading to idiopathic CTS. As previously reported, exceeding the threshold value of tissue stiffness resulted in transformation of fibroblasts into myofibroblasts with alteration in connective tissue characteristics. ${ }^{[19]}$ Actually, it was crucial to prove myofibroblast existence in CTS for both prospects because these cells may have a leading role at final sequence.

In the past, there have been some efforts to show myofibroblast existence by indirect method (lyzil oxidase activity) in carpal tunnel; however, it was never identified directly in SSCT. ${ }^{[20]}$ We were able to prove that myofibroblasts were activated in SSCT samples of early-phase patients. This was statistically significant. Since myofibroblasts were a part of dynamic fibroblast-myofibroblast transformation, it was no surprise for us not to be able to observe these cells in numerous samples. In fact, what we were trying to achieve was to take a "snapshot" of this dynamical process. We assume that we could have a greater chance of observing myofibroblasts if we had included more early-phase patients in our study group.

Other limitations of our study were significant age and gender mismatch between groups. Study group was significantly older than control group and included more female patients. However, a literature survey of previous histopathological studies showed the same limitation about age mismatch, and many studies had even used cadaver samples as control groups. ${ }^{[5,6,18]}$ On the contrary, we used trauma patients as control group, and samples were fresh. Therefore, exclusion criteria were applied properly since we had more accurate medical history than any cadaver study.

Overall, our results confirmed increased fibrosis in SSCT (increased vascular wall thickness, increased collagen type IV reaction) and myofibroblast activation in early-phase of disease. For clarity, determination of exact role of myofibroblasts in CTS may help to enhance new treatment strategies for both preventing and decelerating fibrosis (e.g. Smad protein inhibition, TGF- $\beta$ inhibition) in the disease.

Our study may inspire future studies since we were able to obtain some evidence for myofibroblast activation in idiopathic CTS. Doubtlessly, further research with larger sample sizes would be of great assistance in understanding the role of myofibroblasts in idiopathic CTS.
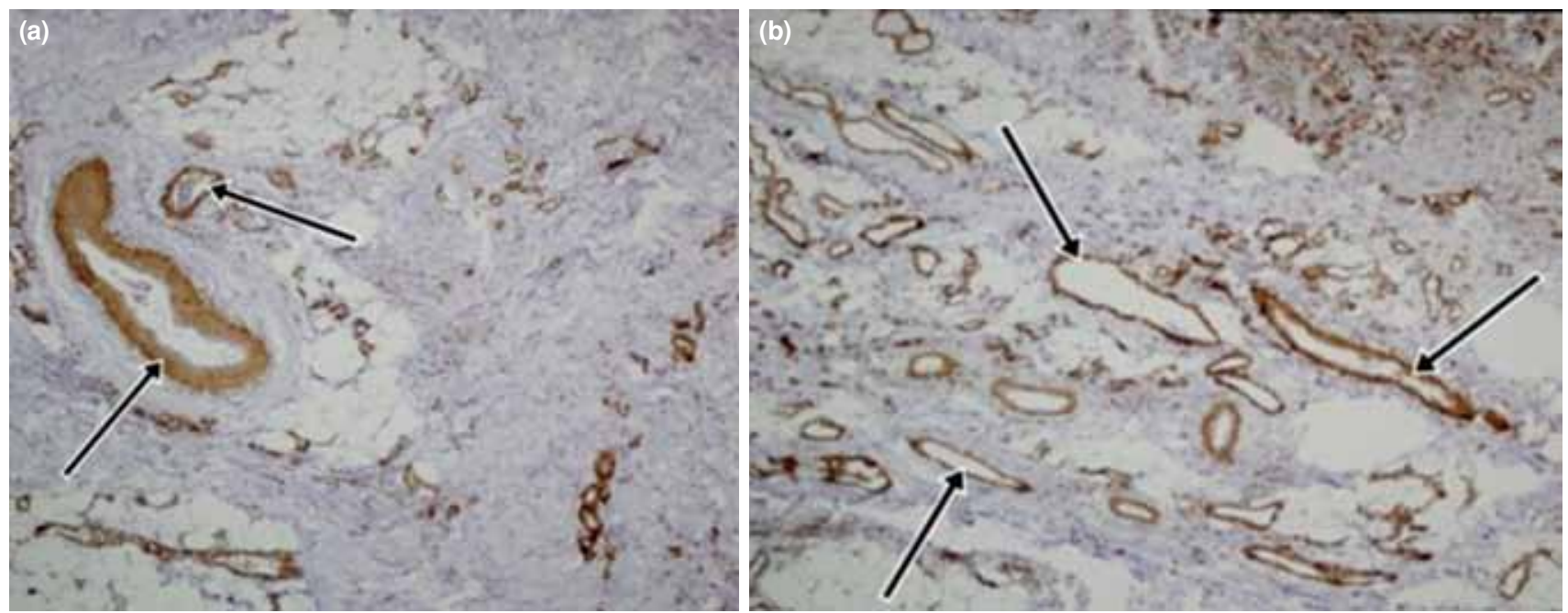

Figure 8. (a) Normal vascularity (arrows) (b) Increased vascularity (arrows), (Anti-human smooth muscle actin x100). 


\section{Acknowledgements}

The authors wish to thank Dokuz Eylül University, Department of Scientific Research Project.

\section{Declaration of conflicting interests}

The authors declared no conflicts of interest with respect to the authorship and/or publication of this article.

\section{Funding}

This study was funded by Dokuz Eylul University, Department of Scientific Research Project.

\section{REFERENCES}

1. Çiftdemir M, Çopuroğlu C, Özcan M, Çavdar L. Carpal tunnel syndrome in manual tea harvesters. Eklem Hastalik Cerrahisi 2013;24:12-7.

2. Szabo RM, Chidgey LK. Stress carpal tunnel pressures in patients with carpal tunnel syndrome and normal patients. J Hand Surg Am 1989;14:624-7.

3. Lin R, Lin E, Engel J, Bubis JJ. Histo-mechanical aspects of carpal tunnel syndrome. Hand 1983;15:305-9.

4. Tucci MA, Barbieri RA, Freeland AE. Biochemical and histological analysis of the flexor tenosynovium in patients with carpal tunnel syndrome. Biomed Sci Instrum 1997;33:246-51.

5. Ettema AM, Amadio PC, Zhao C, Wold LE, An KN. A histological and immunohistochemical study of the subsynovial connective tissue in idiopathic carpal tunnel syndrome. J Bone Joint Surg [Am] 2004;86:1458-66.

6. Yoshii Y, Zhao C, Henderson J, Zhao KD, An KN, Amadio PC. Shear strain and motion of the subsynovial connective tissue and median nerve during single-digit motion. J Hand Surg [Am] 2009;34:65-73.

7. Osamura N, Zhao C, Zobitz ME, An KN, Amadio PC. Evaluation of the material properties of the subsynovial connective tissue in carpal tunnel syndrome. Clin Biomech (Bristol, Avon) 2007;22:999-1003.

8. Yang TH, Thoreson AR, Gingery A, An KN, Larson DR, Zhao $\mathrm{C}$, et al. Collagen gel contraction as a measure of fibroblast function in carpal tunnel syndrome. J Biomed Mater Res A 2014 Apr 20. [Epub ahead of print]

9. Riley GP. Gene expression and matrix turnover in overused and damaged tendons. Scand J Med Sci Sports 2005;15:241-51.

10. Wang JH, Thampatty BP, Lin JS, Im HJ. Mechanoregulation of gene expression in fibroblasts. Gene 2007;391:1-15.

11. Hinz B, Phan SH, Thannickal VJ, Galli A, Bochaton-Piallat ML, Gabbiani G. The myofibroblast: one function, multiple origins. Am J Pathol 2007;170:1807-16.

12. De Wever O, Demetter P, Mareel M, Bracke M. Stromal myofibroblasts are drivers of invasive cancer growth. Int J Cancer 2008;123:2229-38.

13. Millet $C$, Zhang YE. Roles of Smad3 in TGF-beta signaling during carcinogenesis. Crit Rev Eukaryot Gene Expr 2007;17:281-93.

14. William D. Engber, Myofibroblasts and the Carpal Tunnel Syndrome. Iowa Orthop J 1984; 4: 57-59

15. Desmoulière A, Geinoz A, Gabbiani F, Gabbiani G. Transforming growth factor-beta 1 induces alpha-smooth muscle actin expression in granulation tissue myofibroblasts and in quiescent and growing cultured fibroblasts. J Cell Biol 1993;122:103-11.

16. Rotman MB, Donovan JP. Practical anatomy of the carpal tunnel. Hand Clin $2002 ; 18: 219-30$.

17. Ettema AM, Amadio PC, Zhao C, Wold LE, O'Byrne MM, Moran SL, et al. Changes in the functional structure of the tenosynovium in idiopathic carpal tunnel syndrome: a scanning electron microscope study. Plast Reconstr Surg 2006;118:1413-22.

18. Jinrok O, Zhao C, Amadio PC, An KN, Zobitz ME, Wold LE. Vascular pathologic changes in the flexor tenosynovium (subsynovial connective tissue) in idiopathic carpal tunnel syndrome. J Orthop Res 2004;22:1310-5.

19. Hinz B. Tissue stiffness, latent TGF-beta1 activation, and mechanical signal transduction: implications for the pathogenesis and treatment of fibrosis. Curr Rheumatol Rep 2009;11:120-6.

20. Bose KK, Chakraborty J, Khuder S, Smith-Mensah WH, Robinson J. Lysyl oxidase activity in the cells of flexor retinaculum of individuals with carpal tunnel syndrome. J Occup Environ Med 2000;42:582-7. 